\title{
Removal of LPS from a Brucella cytoplasmic fraction by affinity chromatography with an anti-LPS monoclonal antibody as immunosorbent
}

\author{
F. A. GOLDBAUM, C. P. RUBBI and C. A. FOSSATI* \\ Instituto de Estudios de la Inmunidad Humoral (IDEHU) (UBA-CONICET), Facultad de Farmacia y Bioquimica, \\ Junin 956, 1113 Buenos Aires, Argentina
}

\begin{abstract}
Summary. Affinity chromatography on polymyxin B-Sepharose 4B is one of the most commonly used methods for the removal of contaminating lipopolysaccharides (LPS). However, the LPS of Brucella spp. do not bind to polymyxin B. An affinity chromatography method with an anti-O antigen of Brucella LPS monoclonal antibody as immunosorbent was developed. The method produced a 1000-fold reduction in the LPS content of the cytoplasmic fraction of $B$. abortus. The eluted proteins retained their antigenicity. The method, which uses mild physiological conditions, is simple, effective and reproducible.
\end{abstract}

\section{Introduction}

Lipopolysaccharide (LPS) is the immunodominant antigen of the genus Brucella. ${ }^{1}$ Most serological procedures currently used in the diagnosis of brucellosis are based on the detection of anti-LPS antibodies. However, the use of these anti-LPS antibodies in diagnosis presents difficulties: in man, antibody titres remain high even after recovery from the disease ${ }^{2}$ in bovine brucellosis, they cannot be used to differentiate between infected and vaccinated animals; ${ }^{3}$ and more importantly, they are highly cross-reactive with other gram-negative bacteria. ${ }^{4}$ Consequently, the assay of Brucella-protein antibodies provides an alternative approach in the diagnosis of brucellosis.

Since Brucella LPS binds very strongly to both cytoplasmic and membrane proteins, ${ }^{5}$ it is difficult to obtain protein preparations free of LPS contamination. Unlike other gram-negative bacteria, Brucella LPS does not bind to polymyxin $\mathrm{B}^{6}$ and therefore affinity chromatography with polymyxin $B$ cannot be used.

Two strategies have been used in attempts to solve this problem; the extraction of the LPS moiety by chemical procedures $^{7-9}$, the cloning and expression of brucella proteins in Escherichia coli. ${ }^{10,11}$

We report a method to eliminate LPS from a cytoplasmic extract of $B$. abortus by affinity chromatography with an anti-LPS monoclonal antibody (MAb) as immunosorbent.

\section{Materials and methods}

\section{Bacterial culture and preparation of cytoplasmic fraction}

A culture suspension of B. abortus strain 19-S was kindly provided by Laboratories Bagó San Jorge (Argentina). Cells were killed by the addition of formaldehyde $0.4 \% \mathrm{v} / \mathrm{v}$. The cytoplasmic fraction (CYT) was obtained as described by Verstreate et al. ${ }^{12}$ Bacterial suspensions were centrifuged at $16000 \mathrm{~g}$ for $10 \mathrm{~min}$ and washed three times with $10 \mathrm{~mm}$ Tris- $\mathrm{HCl}$, $\mathrm{pH} 8 \cdot 0$. Cells were suspended in Tris buffer $(0.1 \mathrm{~g}$ wet weight $/ \mathrm{ml}$ ) and extruded with an X-Press (Type 25, AB BIOS). The apparatus was cooled to $-26^{\circ} \mathrm{C}$ and the bacterial cells were broken by five successive passages. They were then digested with DNAase $1 \%$ $\mathrm{w} / \mathrm{v}$ and RNAase $1 \% \mathrm{w} / \mathrm{v}$ (Sigma). Unbroken cells were removed by centrifugation at $8000 \mathrm{~g}$. Cell envelopes were harvested by centrifugation at $360000 \mathrm{~g}$ for $2 \mathrm{~h}$. The supernate (CYT) was stored at $-20^{\circ} \mathrm{C}$.

\section{Monoclonal antibody}

MAb BC 68 (IgG, Kappa) was derived by somatic cell hybridisation as described by Galfré and Milstein ${ }^{13}$ with NSO myeloma cells as fusion partners. Mice used for fusion were hyperimmunised with $B$. abortus $19 \mathrm{~S}$ cells which had been inactivated by autoclaving at $121^{\circ} \mathrm{C}$ for $15 \mathrm{~min}$. MAb BC68 was purified by ion exchange chromatography on Q-sepharose in an FPLC P-500 system (Pharmacia). 
acid hydrolysis of brucella S-LPS, by the technique described by Moreno et al. ${ }^{6}$

\section{ELISA}

The method of Voller et al. ${ }^{14}$ was used for the ELISA. All the antigens were adsorbed to Immulon II plates (Dynatech) $-1 \mu \mathrm{g}$ of protein in $50 \mu \mathrm{l}$ of $0.15 \mathrm{M}$ phosphate-buffered saline (PBS), $\mathrm{pH} 7 \cdot 2$, into each well. After blocking with PBS containing skim milk $3 \% \mathrm{v} / \mathrm{v}$ (BS) and washing with PBS plus Tween 20 $0.05 \% \mathrm{v} / \mathrm{v}$ (BST), serum from hyperimmunised mice or ascitic fluid of MAb BC68 diluted 1 in 100 in BST was added and the plates were incubated for $1 \mathrm{~h}$ at room temperature. After washing with BST, $50 \mu \mathrm{l}$ of a peroxidase-conjugated rabbit anti-mouse IgG (Dakopatts) diluted 1 in 1000 in BST was added to each well and the plates were incubated for $1 \mathrm{~h}$ at room temperature. After a further wash, the plates were developed by adding a solution containing $o$-phenylendiamine $2 \mathrm{mg} / \mathrm{ml}$ and $\mathrm{H}_{2} \mathrm{O}_{2} 0.03 \% \mathrm{v} / \mathrm{v}$ in $0.1 \mathrm{M}$ citrate-phosphate buffer, $\mathrm{pH} 5 \cdot 0$. The reaction was stopped by adding $50 \mu \mathrm{l}$ of $2 \mathrm{M} \mathrm{H}_{2} \mathrm{SO}_{4}$ to each well and absorbance was measured at $495 \mathrm{~nm}$ in an ELISA reader (Metrolab).

\section{SDS-PAGE and immunoblotting}

SDS-PAGE was performed with acrylamide $10 \%$ slab gels. ${ }^{15}$

Immunoblotting analysis was performed as described by Tsang et $a l .{ }^{16}$ Serum from five patients with brucellosis was pooled and used at a dilution of 1 in 200 in BS. Ascitic fluid containing MAb BC68 was diluted 1 in 100 in BS.

\section{Chemical analysis}

Proteins were measured by the method of Peterson ${ }^{17}$ with bovine serum albumin (BSA; Sigma) as standard.

The limulus lysate gelation activity (LLGA) of all fractions was determined as described by Sullivan and Watson. ${ }^{18}$ E. coli O111: B4 LPS (Sigma) was used as standard. B. abortus S-LPS was estimated from the ratio of $E$. coli and $B$. abortus LPS gelation activity, i.e., $1 \mathrm{ng}$ of $E$. coli $\mathrm{LPS}$ is equivalent to $1 \mathrm{ng}$ of $B$. abortus S-LPS. ${ }^{6}$

Immunoadsorption of cytoplasmic fraction with BC68Sepharose 4B

Purified MAb BC68 $(5 \mathrm{mg} / \mathrm{ml})$ was coupled to cyanogen bromide-activated Sepharose 4B (Pharmacia), according to the manufacturer's specifications.

For immunoadsorption, $2 \mathrm{ml}$ of BC68-coupled Sepharose 4B gel (BC68-Seph 4B) was incubated with $2 \mathrm{ml}$ of CYT with gentle shaking for $24 \mathrm{~h}$ at $4^{\circ} \mathrm{C}$. After centrifugation or $300 \mathrm{~g}$, the supernate (called "first adsorption") was immunoadsorbed as above, once more. The supernate, named "LPS-free CYT", was diluted 1 in 4 in PBS with respect to the original cytoplasmic fraction. The protein concentration was $0.86 \mathrm{mg} / \mathrm{ml}$.

\section{Agglutination tests}

Direct agglutination tests were performed with equal volumes $(50 \mu \mathrm{l})$ of a suspension of phenol inactivated $B$. abortus $19 \mathrm{~S} 3 \% \mathrm{v} / \mathrm{v}$ in saline $0.85 \%$ containing phenol $0.5 \% \mathrm{v} / \mathrm{v}$ and antibody.

\section{Results}

MAb BC68 is specific for the repetitive epitope of the $O$ antigen of brucella LPS. It agglutinates smooth cells of different Brucella species and also Yersinia enterocolitica $\mathrm{O} 9$ in which the $\mathrm{O}$ antigen is identical to brucella $\mathrm{O}$ antigen. MAb BC68 reactivity against CYT was inhibited by adsorption with the smooth $B$. abortus 19-S strain, but not with the rough $B$. abortus $45 / 20$ strain. The reactivity of MAb BC68 against CYT was not abolished by previous digestion of this antigen

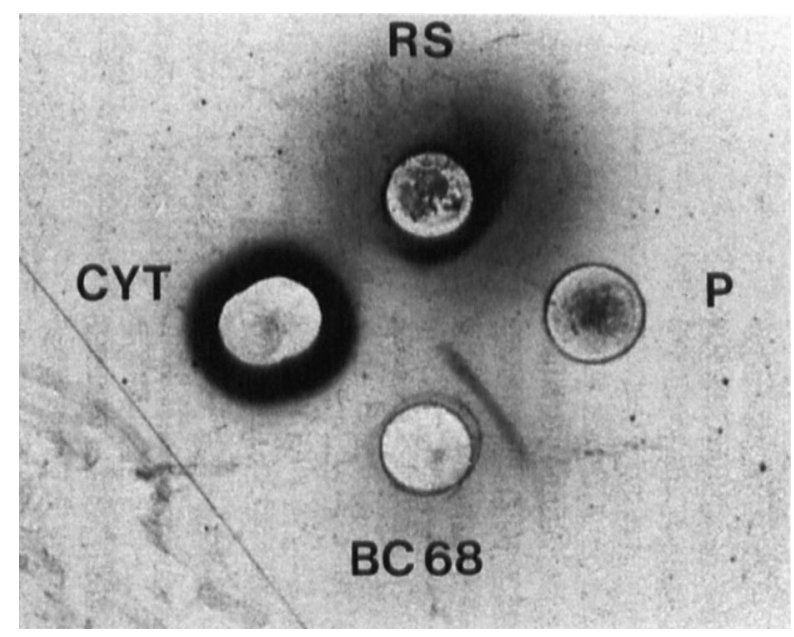

Fig. 1. Ouchterlony analysis of MAb BC68. CYT, B. abortus cytoplasmic fraction; RS, serum from a rabbit hyperimmunised with $B$. abortus; P, polysaccharide fraction of $B$. abortus S-LPS obtained by mild acid hydrolysis.

Table. Removal of LPS from CYT with BC68-Sepharose 4B

\begin{tabular}{lcc}
\hline $\begin{array}{l}\text { Fraction } \\
\text { analysed }\end{array}$ & $\begin{array}{c}\text { Protein } \\
\text { concentration } \\
(\mathrm{mg} / \mathrm{ml})\end{array}$ & $\begin{array}{c}\text { LPS } \\
\text { concentration* } \\
(\mathrm{mg} / \mathrm{ml})\end{array}$ \\
\hline CYT & 3.6 & $8 \cdot 9-12.5$ \\
LPS-free† CYT & 3.4 & $7 \cdot 2-10.0 \times 10^{-3}$ \\
\hline
\end{tabular}

* Calculated from the LLGA test.

$\dagger$ Concentrations in LPS-free CYT were corrected for dilution due to immunoadsorption. 


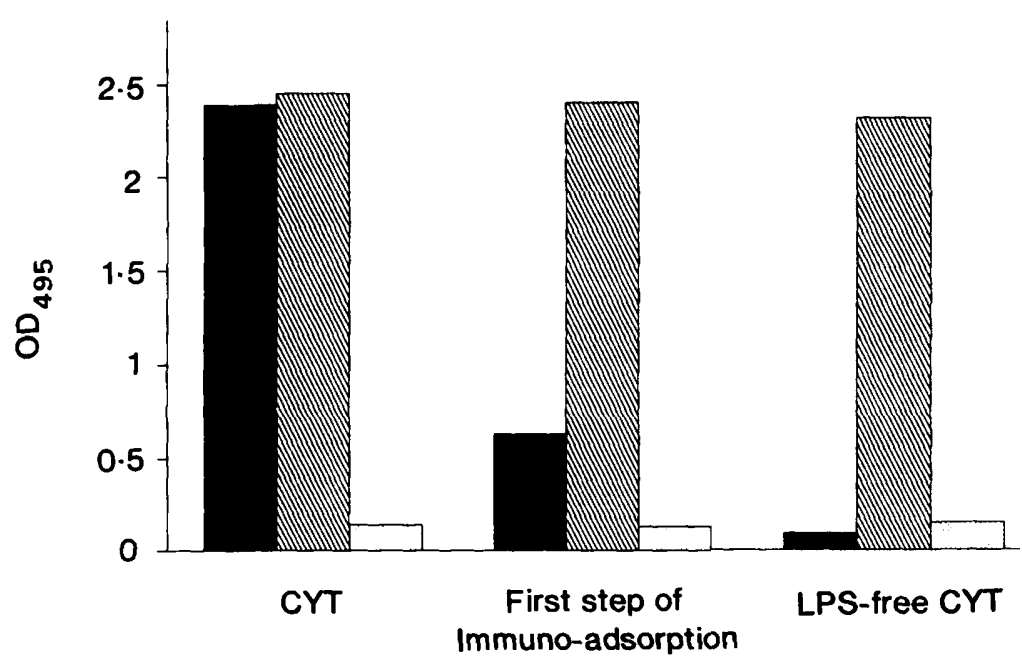

Fig. 2. ELISA analysis of CYT and the eluted material of the two steps of affinity chromatography with BC68-Sepharose B4: $\square$, ascitic fluid of MAb BC68; serum of a mouse hyperimmunised with B. abortus; 图, normal mouse sera.
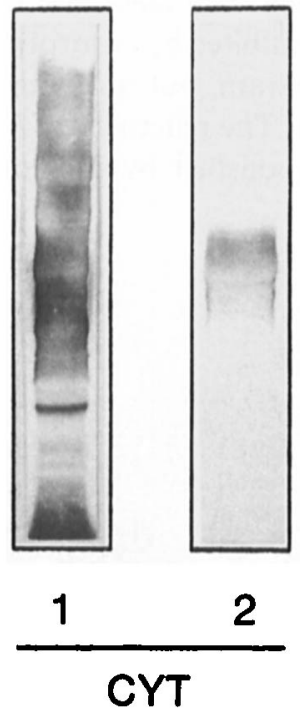
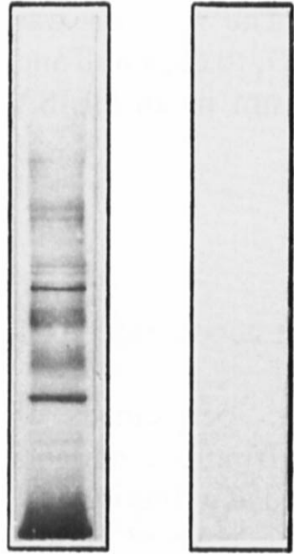

2

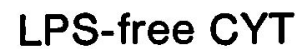

Fig. 3. Immunoblot analysis of CYT and "LPS-free CYT" with: 1, pooled serum from patients with brucellosis; 2, ascitic fluid containing MAb BC68.

with proteinase $\mathrm{K}$ (Sigma) $50 \mu \mathrm{g} / \mathrm{ml}$ (results not shown). In the Ouchterlony assay, MAb BC68 precipitated with the polysaccharide fraction obtained by mild acid hydrolysis of S-LPS (fig. 1). However, MAb BC68 did not precipitate CYT fraction although it has a high content of LPS. This may be due to the low diffusion of the LPS molecule. Rabbit antiserum, on the other hand, produced a diffuse precipitation band against both CYT and the polysaccharide fraction.

The high avidity shown by MAb BC68, manifest by the high titres developed in both ELISA and agglutination systems ( $>200000$ and 2000, respectively) make this MAb a suitable immunosorbent. Therefore, we used it coupled to Sepharose 4B in affinity chromatography to deplete the CYT fraction of LPS. The eluted material of the second step of immuno- adsorption ("LPS-free CYT") showed a 1000-fold reduction in LPS content (table).

CYT and the eluted material obtained after the two steps of affinity chromatography were analysed by ELISA with MAb BC68 and serum from a mouse hyperimmunised with $B$. abortus (fig. 2). The reactivity with MAb BC68 decreased by $75 \%$ after the first step of adsorption and even further after the second step ("LPS-free CYT"). The material eluted from affinity chromatography retained its antigenicity and reactivity against the hyperimmune serum.

Immunoblotting with CYT and "LPS-free CYT" studies (fig. 3) gave similar results. Pooled serum from patients with brucellosis produced a broad smear with some well-defined protein bands against CYT. In contrast, a clear well-defined pattern of protein bands 
was obtained with "LPS-free CYT". This showed that the protein bands were masked by the LPS present in CYT. Most of the protein bands developed by the hyperimmune serum remain after immunoadsorption with MAb BC68 (fig. 2).

As a control, both antigens were developed with MAb BC68. The results show that the LPS content of CYT had been reduced by immunoadsorption to a level which was no longer detectable.

\section{Discussion}

Brucella LPS differs from the LPS of other gramnegative bacteria. These differences involve both lipid $\mathrm{A}$ and the "backbone". ${ }^{6,19}$ Consequently, brucella LPS does not bind to polymyxin $\mathbf{B}^{6}$, an antibiotic capable of irreversibly binding LPS from most gramnegative bacteria. Polymyxin B-sepharose is often used to reduce the LPS contamination of macromolecular solutions. ${ }^{20-22}$

Removal of brucella LPS by chloroform-petroleum ether-phenol extraction ${ }^{9}$ or trichloroacetic acid (TCA) precipitation followed by sonication ${ }^{7,8}$ has been reported. However, these methods produce extensive protein denaturation, especially TCA precipitation.

Although there are several anti-brucella LPS MAbs, there are no reports of these being used to remove brucella LPS.

Immunoadsorption with BC68-Sepharose 4B, in common with affinity chromatography with poly- myxin B, employs mild physiological conditions, which permit the recovery of proteins without denaturation. ${ }^{21}$ By using MAb BC68 as immunoadsorbent, a $10^{3}$-fold reduction of LPS content of CYT was achieved. Studies using polymyxin B to remove LPS from other gram-negative genera have reported reductions of $10^{3}-10^{5}$-fold. ${ }^{20-22}$ However, in these reports the LPS was merely a contaminent (up to $\mu \mathrm{g} / \mathrm{ml}$ quantities), whereas in this work brucella LPS was present in concentrations in the order of $\mathrm{mg} / \mathrm{ml}$ in the cytoplasmic fraction.

It is not clear whether the remaining LLGA present in "LPS-free CYT" is due to a trace amount of nonextracted S-LPS, or to the presence of either R-LPS or lipid A, either of which can produce gelation. However, this was not detected by the immunochemical methods and, consequently, did not interfere with the detection of anti-protein antibodies. We have shown previously that the "LPS-free CYT" antigenic fraction prepared by this method can be used to measure the humoral immune response to brucella proteins without interference by anti-LPS antibodies. ${ }^{23}$

In conclusion, removal of LPS by affinity chromatography with an anti-LPS MAb can be used to prepare brucella LPS-free protein extracts. The method is simple, effective and reproducible.

This research was financed by grants from Consejo Nacional de Investigaciones Cientifioas y Técnicas (CONICET) and Universidad de Buenos Aires (UBA), F.A.G. is a recipient of a fellowship of UBA and C.A.F. is member of the Carrera del Investigador del CONICET and member of the Facultad de Ciencias Exactas, Universidad Nacional de La Plata.

\section{References}

1. Plommet M, Serre A, Fensterbank R. Vaccines, vaccination in brucellosis. Ann Inst Pasteur Microbiol 1987; 138: 117-121.

2. Pellicer T, Ariza J, Foz A, Pallares R, Gudiol F. Specific antibodies detected during relapse of human brucellosis. $J$ Infect Dis 1988; 157: 918-924.

3. Wright PF, Nielsen KH. Current and future serological methods. In: Adams L G (ed) Advances in brucellosis research. Texas A and M University Press. 1990: 305-320.

4. Corbel MJ. Recent advances in the study of Brucella antigens and their serological cross-reactions. Vet Bull 1985; 55: 927-942.

5. Winter AJ. Outer membrane proteins of Brucella. Ann Inst Pasteur Microbiol 1987; 138: 87-89.

6. Moreno E, Berman DT, Boettcher LA. Biological activities of Brucella abortus lipopolysaccharides. Infect Immun 1981; 31: 362-370.

7. Winter AJ, Verstreate DR, Hall CE et al. Immune response to porin in cattle immunized with whole cell, outer membrane, and outer membrane protein antigens of Brucella abortus combined with trehalose dimycolate and muramyl dipeptide adjuvants. Infect Immun 1983; 42: 1159-1167.

8. Baldwin CL, Verstreate DR, Winter AJ. Immune response of cattle to Brucella abortus outer membrane proteins measured by lymphocyte blastogenesis. Vet Immunol Immunopathol 1985; 9: 383-396.

9. Riezu-Boj JI, Moriyón I, Blasco JM, Gamazo C, Díaz R. Antibody response to Brucella ovis outer membrane proteins in ovine brucellosis. Infect Immun 1990; 58: 489-494.

10. Bricker BJ, Tabatabai LB, Judge BA, Deyoe BL, Mayfield JE.
Cloning, expression, and occurrence of the Brucella $\mathrm{Cu}-\mathrm{Zn}$ superoxide dismutase. Infect Immun 1990; 58: 2935-2939.

11. Lin J, Adams LG, Ficht TA. Characterization of the heat shock response in Brucella abortus and isolation of the genes encoding the GroE heat shock proteins. Infect Immun 1992; 60: 2425-2431.

12. Verstreate DR, Creasy MT, Caveney NT, Baldwin CL, Blab MW, Winter AJ. Outer membrane proteins of Brucella abortus: isolation and characterization. Infect Immun 1982; 35: 979-989.

13. Galfré G, Milstein C. Preparation of monoclonal antibodies: strategies and procedures. Methods Enzymol 1981; 73ptB: $3-46$.

14. Voller A, Bidwell DE, Huldt G, Engvall E. A microplate method of enzyme-linked immunosorbent assay and its application to malaria. Bull World Health Organ 1974; 51 : 209-211.

15. Laemmli UK. Cleavage of structural proteins during the assembly of the head of bacteriophage T4. Nature 1970; 227: 680-685.

16. Tsang VCW, Peralta JN, Simons AR. Enzyme-linked immunoelectrotransfer blot techniques (EITB) for studying the specificities of antigens and antibodies separated by gel electrophoresis. Methods Enzymol 1983; 92: 377-391.

17. Peterson GL. A simplification of the protein assay method of Lowry et al. which is more generally applicable. Anal Biochem 1977; 83: 346-356.

18. Sullivan JD, Watson SW. Factors affecting the sensitivity of Limulus lysate. Appl Microbiol 1974; 28: 1023-1026.

19. Mayer H, Weckesser J. "Unusual" Lipid A's: structures, taxonomical relevance and potential value for endotoxin research. In: Rietschel E T (ed) Handbook of endotoxin, 
vol 1. Chemistry of endotoxin. Amsterdam, Elsevier Science Publishers BV. 1984: 221-247.

20. Issekutz AC. Removal of Gram-negative endotoxin from solutions by affinity chromatography. $J$ Immunol Methods 1983; 61: 275-281.

21. Karplus TE, Ulevitch RJ, Wilson CB. A new method for reduction of endotoxin contamination from protein solutions. J Immunol Methods 1987; 105: 211-220.
22. Wilder JA, Cowdery JS, Ashman RF. The influence of lipopolysaccharide content on the apparent B cell stimulating activity of anti- $\mu$ preparations. $J$ Immunol Methods 1988; 110: 63-68.

23. Goldbaum FA, Rubbi CP, Wallach JC, Miguel SE, Baldi PC, Fossati CA. Differentiation between active and inactive human brucellosis by measuring antiprotein humoral immune responses. J Clin Microbiol 1992; 30: 604-607. 